\title{
TGF- $\beta$ in intestinal lymphoid organs contributes to the death of armed effector CD8 T cells and is associated with the absence of virus containment in rhesus macaques infected with the simian immunodeficiency virus
}

\author{
MC Cumont ${ }^{1}$, V Monceaux ${ }^{1}$, L Viollet ${ }^{1}$, S Lay ${ }^{1}$, R Parker ${ }^{1}$, B Hurtrel ${ }^{1,3}$ and J Estaquier, ${ }^{\star, 1,2}$
}

SIV-infected macaques exhibit distinct rates of progression to AIDS and despite significant increases in CD8 ${ }^{+} \mathrm{T}_{\text {cells, }}$ immune cells fail to control and eradicate SIV in vivo. Here, we investigated the interplay between viral reservoir sites, CD8 ${ }^{+}$T-cell activation/death and outcome. Our data provide strong evidence that mesenteric (Mes) lymph nodes represent major reservoirs not only for SIV-infected macaques progressing more rapidly toward AIDS but also in controllers. We demonstrate that macaques progressing faster display greater expression of TGF- $\beta$ and Indoleamine 2,3 dioxygenase in particular in intestinal

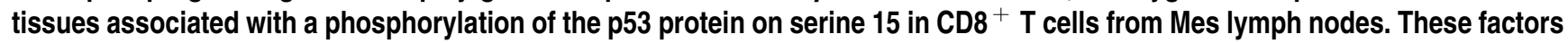
may act as a negative regulator of $\mathrm{CD8}^{+}{ }^{-} \mathrm{T}$-cell function by inducing a Bax/Bak/Puma-dependent death pathway of effector/ memory $\mathrm{CDB}^{+} \mathrm{T}$ cells. Greater T-cell death and viral dissemination was associated with a low level of TIA-1 ${ }^{+}$expressing cells. Finally, we provide evidence that abrogation of TGF- $\beta$ in vitro enhances T-cell proliferation and reduces CD8 ${ }^{+}$T-cell death. Our data identify a mechanism of T-cell exhaustion in intestinal lymphoid organs and define a potentially effective immunological strategy for the modulation of progression to AIDS.

Cell Death and Differentiation (2007) 14, 1747-1758; doi:10.1038/sj.cdd.4402192; published online 6 July 2007

Virus production in Human Immunodeficiency Virus 1 (HIV-1)infected individuals is largely the result of a dynamic process involving continuous rounds of de novo infection and replication in $\mathrm{CD}_{4}{ }^{+}$cells with rapid turnover of both free virus and virus producing cells. Moreover, an increasing body of evidence suggests that reservoirs, cell types or anatomical sites ('sanctuaries'), represent a major barrier to virus eradication. ${ }^{1}$

HIV-specific CD8 ${ }^{+}$T lymphocytes (CTL) are considered crucial in the control of viral replication. ${ }^{2}$ Excessive induction of apoptosis has been proposed as one major mechanism of abnormal T-cell response during HIV and Simian Immunodeficiency Virus (SIV) infections. ${ }^{3}$ However, most studies, which investigated the potential relationship between HIV and SIV infections and apoptosis have focused on cells from peripheral blood, rather than on cells from lymphoid organs.

Peripheral lymphoid tissues such as the axillary and inguinal (Ing) lymph nodes (LNs), which drain the arms and legs, respectively, and the spleen, are considered major sites of HIV/SIV replication. ${ }^{4}$ Accumulating data also indicate that gut-associated lymphoid tissue (GALT), which contains inductive sites, Peyer's patches and mesenteric (Mes) LNs, and effectors sites located within lamina propria and epithelium of the intestinal wall, is also an early and predominant tissue site of viral replication and may be a reservoir for HIV/SIV. ${ }^{5,6}$

Because $T$ cells from the GALT are required to maintain a state of immunological tolerance toward a myriad of dietary and resident bacterial antigens, the chronic exposure of HIV/ SIV-specific antigens could have an impact on the capacity of $\mathrm{CD}^{+}{ }^{+} \mathrm{T}$ cells to control viral replication in the GALT.

Addressing these complex pathways in HIV-1 infected patients is limited by the access to internal tissue biopsies, and therefore macaques provide a useful model to address and explore these fundamental questions of the anatomical viral reservoirs and the dynamics of effector cells that control viral replication. We examined organs from 12 monkeys (controllers versus non-controllers), sampling peripheral blood, Ing and Mes LNs, spleen, jejunum, colon, ileum, lung, kidney and liver. Collectively, our data demonstrated that Mes LNs represent critical reservoirs for SIV. The absence of immune control, in macaques progressing faster to Acquired Immunodeficiency Syndrome (AIDS), occurs in the context of greater expression of immunosuppressive factors and abnor-

\footnotetext{
${ }^{1}$ CNRS URA 1930; Unité de Physiopathologie des Infections Lentivirales, Institut Pasteur, 28 rue du Docteur Roux, Paris, France and ${ }^{2}$ INSERM U 841 , Créteil, Paris, France

${ }^{*}$ Corresponding author: J Estaquier, Unité de Physiopathologie des Infections Lentivirales, Institut Pasteur, 28 rue du Docteur Roux, Batiment Lwoff, Paris, 75724 cedex 15, France. Tel: + 331456889 01; Fax: + 331406134 50; E-mail: estaquier@yahoo.fr

${ }^{3}$ This work is dedicated to the memory of $\mathrm{BH}$.

Keywords: AIDS; reservoir; IDO; apoptosis; PD-1; p53

Abbreviations: AIDS, Acquired Immunodeficiency Syndrome; SIV, Simian Immunodeficiency Virus; HIV, Human Immunodeficiency Virus; LN, lymph node; IDO, indoleamine 2,3 dioxygenase; GALT, gut-associated lymphoid tissue; PD-1, programmed death 1; AICD, activation-induced cell death; CTL, cytotoxic T lymphocyte Received 28.11.06; revised 14.5.07; accepted 15.5.07; Edited by G Rabinovich; published online 06.7.07
} 
mal death of effector/memory $\mathrm{CD}^{+} \mathrm{T}$ cells and TGF- $\beta$ appears to be a key factor in controlling $\mathrm{CD} 8^{+} \mathrm{T}$-cell death.

\section{Results}

Mes LNs are major reservoirs for SIV RNA ${ }^{+}$cells. The monkey's respective blood CD4 T-cell counts, viral loads and evidence of clinical wasting syndrome (cachexia, weight loss and opportunistic infections) are summarized in Figure 1a and Table 1. Seven non-controllers (NC) animals were humanely euthanized due to signs of wasting syndrome (two progressing faster to AIDS: \#94852 and \#272, NC/FP). The others were controllers $(\mathrm{C})$, including a monkey defined as a long-term non-progressor (LTNP), killed at 108 months postinfection (\#P4) and four defined as slow progressors (SPS) without signs of AIDS and euthanized at 18-51 months post-infection, for comparative analysis. Viral loads were higher in non-controllers $\left(>10^{5}\right.$ copies $\left./ \mathrm{ml}\right)$ than in controllers ( $<10^{5}$ copies $/ \mathrm{ml}, \quad P=0.02$ ), during the chronic phase (Figure 1b), while no difference was observed during the acute phase. Slope CD4 T-cell decrease per month was higher in non-controllers than in controllers (Figure 1b).

We looked for productively infected cells and diffuse labeling over the follicular dendritic cell (FDC) network in the germinal center (GC), corresponding to virus trapped at the FDC surface (silver grains). In all cases examined, we found SIV RNA ${ }^{+}$cells even in the LTNP, as shown in representative animals from each group in Figure 1c. Spleen and Ing LNs were significant sites for productively infected cells (Figure 1c). SIV RNA ${ }^{+}$cells were most often detected in non-controllers than in controllers (Figures $1 \mathrm{a}$ and $\mathrm{d}$ ).

Most importantly, our data demonstrated that the frequency of SIV RNA ${ }^{+}$cells in controllers and non-controllers, was markedly higher in Mes LNs than in the other organs or LNs (Figures $1 \mathrm{c}$ and $\mathrm{d}$ ). It is interesting to note that even in the LTNP, SIV RNA ${ }^{+}$cells were also detected in Mes LNs, despite the absence of detectable plasma viral load for almost 10 years after infection, supporting the notion that the virus is stored throughout the long course of infection in this organ. Our data also demonstrated that SIV RNA ${ }^{+}$cells and trapped viruses (Figures 1c and d) are detected at high levels within the jejunum, the ileum and the colon in macaque \#272. In contrast, few SIV RNA ${ }^{+}$cells were detected in the lymphoid zones of the colon in the other monkeys, and none was detected in the controllers. One argument might be that the absence of SIV RNA ${ }^{+}$cells in the GALT could be due to the absence of SIV-targets cells. We therefore analyzed the tissues for frequencies of CD4 and macrophages. Whereas less $\mathrm{CD} 4^{+} \mathrm{T}$ cells was detected in the lamina propria, $\mathrm{CD} 4{ }^{+} \mathrm{T}$ cells were clearly present in the organized aggregates (Peyer's patches and lymphoid follicles), without evidence of extensive CD4 depletion in infected versus non-infected controls. Moreover, although in FP macaque \#272, the numbers of $\mathrm{CD}^{+}{ }^{+} \mathrm{T}$ cells were low, intense viral replication was observed. Therefore, we also analyzed for the presence of macrophages (CD68) and found large numbers of this nonlymphoid population in all the monkeys, both in the lamina propria as well as in the organized aggregates. Thus, viral detection was likely due to the presence of these target cells
(Supplementary data S1). We also detected SIV RNA ${ }^{+}$cells in non-lymphoid tissues such as liver, kidney and lung of FP macaque \#272, while they were undetectable in equivalent tissues from other monkeys (data not shown).

These results provide strong evidence that Mes LNs represent major reservoirs not only for animals progressing more rapidly toward AIDS but also in LTNP.

Induction of TGF- $\beta$ and IDO contributes to the pathogenesis of SIV infections in vivo. Given that immunosuppressive factors have recently been reported to be increased in the periphery of SIV-infected macaques during acute phase, ${ }^{7}$ we analyzed the expression of TGF- $\beta$, indoleamine 2,3 dioxygenase (IDO) and interleukin 10 (IL-10) in the different lymphoid tissues. In macaques progressing faster toward AIDS, a higher expression of TGF- $\beta$ was noted in the B-cell (GCs staining) and T-cell areas. TGF- $\beta$ was 2- to 4-fold higher in Mes LNs than in the other organs (Figures 2a and $\mathrm{c}$ ). TGF- $\beta$ overexpression has been shown to be an important mediator of fibrosis. During HIV infection, ${ }^{8}$ as well as in SIV-infected macaques (data not shown), extensive remodeling of lymphoid organs also occurs, with fibrotic changes and destruction of the architecture. These changes are therefore consistent with our finding of elevated TGF- $\beta$ expression. Whereas suppressive T cells produce TGF- $\beta$, a large variety of additional cell lineages have been reported to produce this cytokine. ${ }^{9}$ Herein, immunohistochemical analysis indicated that antibody against TGF- $\beta$ also stains cells with typical morphology of non-lymphoid cells (Figure 2a). Analyses of TGF- $\beta$ in the GALT (jejunum, ileum and colon) also revealed greater expression of this mediator in monkeys progressing faster to AIDS (Figure 3a). IL-10 also contributes to the absence of inflammation in normal intestinal mucosa in vivo. ${ }^{10}$ However, a decrease of IL-10 was observed in various tissues analyzed from SIVinfected macaques (data not shown).

IDO is a cytoplasmic enzyme involved in tryptophan catabolism, blockage of T-cell activation and induction of death. ${ }^{11}$ Immunostaining for IDO in the different organs demonstrated higher numbers of IDO ${ }^{+}$cells in B cell- (GC staining) and T-cell areas of Mes LNs than in the other organs, as well as higher levels in Mes LNs of macaques progressing faster to AIDS (Figures $2 \mathrm{~b}$ and $\mathrm{d}$ ). Similar to TGF- $\beta$, we found greater numbers of IDO ${ }^{+}$cells in the GALT of non-controllers than in controllers (Figure $3 \mathrm{~b}$ ). It has been also shown that IDO is strongly expressed in macrophages and dendritic cells (DCs). ${ }^{11}$ Herein, IDO immunostaining identified cells displaying a non-lymphoid morphological phenotype (Figure $2 b$ ).

Thus, our data identified IDO and TGF- $\beta$ in the lymphoid tissues as potential markers for AIDS progression, and these mediators might contribute to a significant extent to immunosuppression or blunting the local antiviral defenses.

Expression of the p53 protein in $\mathrm{CD}^{+} \mathrm{T}$ cells of Mes LNs from SIV-infected macaques. Given that the transcription factor p53 has been shown to mediate cellular response to various stressors, in particular the phosphorylated form of p53 on serine 15 (p53S15P), and the fact that p53 contributes to TGF- $\beta$-mediated growth arrest in mammalian cells, ${ }^{12}$ we next evaluated the expression of p53S15P to gain 

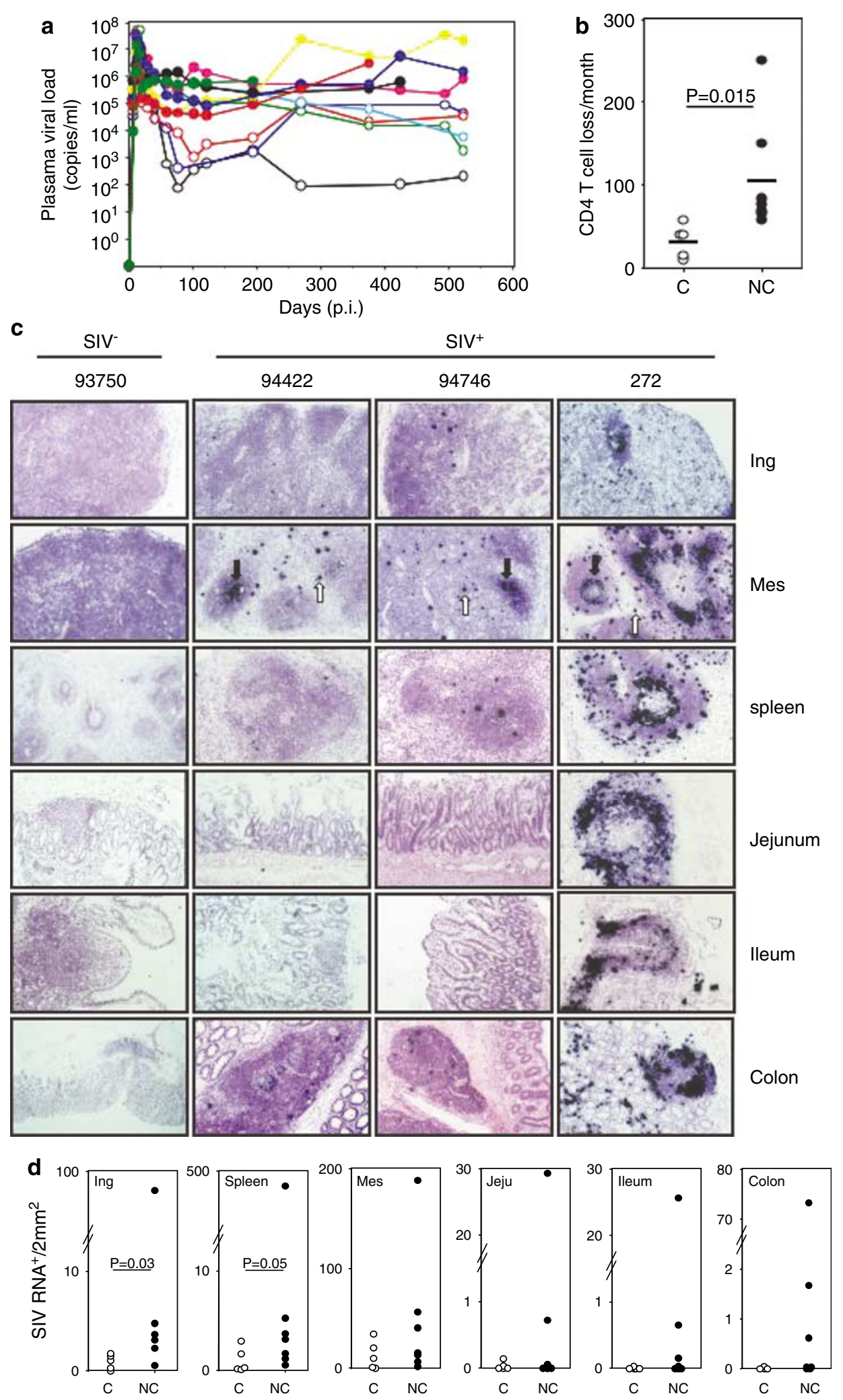

Figure 1 Productive SIV infection. (a) Kinetic analysis of viral load in controllers (C, open circles) and non-controllers (NC, filled circles). Statistical analysis was assessed using the Student's t-test. (b) Slope CD4 T-cell decrease per month in controllers $(C)$ and non controllers (NC). Each symbol represents an individual. (c) SIV RNA ${ }^{+}$cells were detected in Ing and Mes LNs, in the spleen, jejunum, ileum and colon of uninfected (\#93750) and SIV-infected macaques displaying distinct rate of progression toward AIDS (controller, \#94422 (C), non-controller \#94746 (NC) and non-controller/fast progressor \#272 (NC/FP)). White arrows indicate SIV RNA ${ }^{+}$cells and black arrows indicate SIV trapping (magnification, $\times 100$ ). (d) Quantitation of SIV RNA ${ }^{+}$cells in controllers (C) and non-controllers (NC). Statistical analysis was assessed using the Mann-Whitney U-test 
Table 1 Characteristics of animals used in this study

\begin{tabular}{lccc}
\hline Macaques & Month p.i. & Wasting syndrome & CD4 T-cell counts \\
\hline P4 & 108 & - & 709 \\
264 & 51 & - & 1020 \\
94422 & 18 & - & 447 \\
276 & 18 & - & 822 \\
268 & 26 & - & 58 \\
266 & 17 & + & 74 \\
94780 & 19 & + & 291 \\
94438 & 21 & + & 181 \\
94748 & 18 & + & 223 \\
94746 & 20 & + & 110 \\
94852 & 12 & + & 50 \\
272 & 5 & & 713 \\
\hline
\end{tabular}

${ }^{\mathrm{a}} \mathrm{CD} 4 \mathrm{~T}$-cell counts $/ \mathrm{mm}^{3}$ at the day of killing.

further insight into the regulation of $\mathrm{CD}^{+} \mathrm{T}$ cells in vivo, in the context of immunosuppressive factors. We demonstrated that CD8 ${ }^{+}$T cells of SIV-infected macaques display a higher proportion of $\mathrm{p} 53 \mathrm{~S} 15 \mathrm{P}^{+}$in non-controllers than $\mathrm{CD}^{+}$ $T$ cells from uninfected or infected but controller macaques. These expression differences were only significant in Mes LNs (Figures $4 a$ and $b$ ). Interestingly, the difference in the frequencies of p53S15P ${ }^{+}$in $\mathrm{CD}^{+}{ }^{+}$T cells between Mes LNs and Ing LNs was consistent with our findings relative to the frequencies of cycling $\mathrm{CD}^{+}{ }^{+} \mathrm{T}$ cells. Indeed, by measuring the expression of the nuclear antigen Ki67 in these compartments, we found a significantly higher proportion of cycling CD8 ${ }^{+}$T cells in Ing LNs of SIV-infected macaques, compared with healthy macaques (Figure 4c). The proportion of cycling $\mathrm{CD}^{+} \mathrm{T}$ cells in Ing LNs was higher than in Mes LNs. The percentage of cycling $\mathrm{CD}^{+}{ }^{+} \mathrm{T}$ cells in Ing LNs correlated with the extent of plasma viral load (Figure 4d), consistent with previous findings and predicts disease evolution. ${ }^{13,14}$ In contrast, no correlation was observed for this parameter in Mes LNs (data not shown). Thus, our results demonstrated for the first time distinct T-cell dynamics between peripheral and secondary lymphoid tissues in SIV-infected macaques.

Effector/memory CD8 ${ }^{+} \mathbf{T}$ cells from Mes LNs of SIVinfected macaques are more prone to die. Given the increased expression of the phosphorylated form of p53, we next assessed the expression of proapoptotic target gene products such as Bax, Bak and PUMA, focusing on CD8 ${ }^{+}$ $T$ cells from Mes LNs. Our data clearly demonstrated higher PUMA expression as well as higher expression of Bax and Bak and/or their conformational changes (active forms of Bak and Bax) in Mes LNs of SIV-infected macaques (Figures 5a and b) compared to non-infected macaques. The expression of Bax, Bak and PUMA was greater in non-controllers than in controllers. Thus, by plotting the proportion of $\mathrm{p}^{2} 3 \mathrm{~S} 15 \mathrm{P}^{+}$ cells against the levels of Bak, Bax and PUMA expression, we demonstrated a positive relationship between these parameters in Mes LNs (Figure 5c). Because Bax, Bak and PUMA are considered key factors controlling mitochondrial damage and cell death, we next tested whether CD8 ${ }^{+}$T cells from Mes LNs were more prone to death. Although we found higher numbers of TUNEL ${ }^{+}$cells in tissues of SIV-infected macaques progressing faster to AIDS (data not shown), this technique may underestimate the true extent of T-cell death, as clearance of apoptotic cells in vivo is a highly efficient process. Thus, to circumvent this caveat and address this question, $\mathrm{CD}^{+} \mathrm{T}$ cells from Mes $\mathrm{LNs}$ were isolated from healthy and SIV-infected macaques and incubated overnight in the absence of additional stimuli. We demonstrated that $\mathrm{CD}^{+} \mathrm{T}$ cells collected from SIV-infected macaques were more prone to death in vitro than $\mathrm{T}$ cells from healthy macaques (Figure 5d). Interestingly, we found that the rates of spontaneous $\mathrm{CD}^{+}{ }^{+} \mathrm{T}$-cell death are higher in SIV-infected macaques progressing faster to AIDS, than in controllers. This result supports the notion that abnormal priming for death in $\mathrm{CD}^{+} \mathrm{T}$ cells from secondary lymphoid organs is associated with greater expression of proapoptotic molecules and may contribute to immune incompetence.

In order to define the phenotype of the dying T cells, we performed quadruple color staining. Given that quantification of dying cells expressing CCR7, a marker of T-cell differentiation, was precluded due to technical constraints, we assessed dying subpopulations based on the CD45RA and CD27 molecules from Mes LNs of healthy and SIV-infected macaques (\#266, \#94780, \#94438, \#94748 and \#94746). We found that $\mathrm{CD} 8^{+} \mathrm{T}$-cell subsets of healthy macaques that were more prone to die were from the CD45RA ${ }^{-} 27^{-}$(effector/ memory $\mathrm{T}$ cells) and CD45RA ${ }^{+} \mathrm{CD}^{-} 7^{-}$(terminally differentiated $T$ cells) subsets (Figure $5 e$ ). Most importantly, our data demonstrated that the majority of the dying $\mathrm{CD}^{+}{ }^{+} \mathrm{T}$-cell subsets of SIV-infected macaques were CD45RA ${ }^{-}$CD27 ${ }^{-}$ populations representing 2 - to 4 -fold the rates observed in healthy macaques. In contrast, the proportion of dying $\mathrm{CD} 5 \mathrm{RA}^{+} \mathrm{CD}^{-} 7^{-}$subsets in both healthy and SIV-infected macaques was not significantly different. Our data therefore indicate that the death of effector/memory T cells in Mes LNs might, at least in part, participate in the absence of viral containment in non-controllers favoring viral dissemination.

Expression of PD-1 on CD8 ${ }^{+}$T cells of Mes LNs from SIVinfected macaques. Given that the protein programmed death 1 (PD-1) was originally isolated from a cytotoxic T-cell line, CTTL-2, following stimuli that promote apoptosis, ${ }^{15}$ and induces exhaustion of $\mathrm{CD}^{+}{ }^{+} \mathrm{T}$ cells during chronic viral infection, ${ }^{16}$ we decided to determine whether the expression of PD-1 is more abundantly expressed on CD8 ${ }^{+} \mathrm{T}$ cells from Mes LNs of SIV-infected macaques. Our data demonstrated that PD-1 is expressed at higher frequency and density on $\mathrm{CD}^{+} \mathrm{T}$ cells from non-controllers than controllers or uninfected macaques (Figures $6 a$ and b). We next assessed whether TGF- $\beta$ affects the expression of PD-1. We found that activation-induced PD-1 expression was enhanced by incubation in the presence of TGF- $\beta$ (Figure 6c). Interestingly, despite greater expression of PD-1 on $\mathrm{CD}^{+}{ }^{+} \mathrm{T}$ cells following $\mathrm{T}$-cell activation, no cell death was observed in $\mathrm{CD}^{+} \mathrm{T}$ cells from healthy macaques (data not shown).

Impairment of TIA-1 expression in Mes LNs of SIVinfected macaques. TIA-1 that is functionally related to perforin has been shown to be expressed by effector/ memory cells. ${ }^{17}$ As shown in Figure 7, the extent of immunohistochemical staining in Mes LNs was greater in 


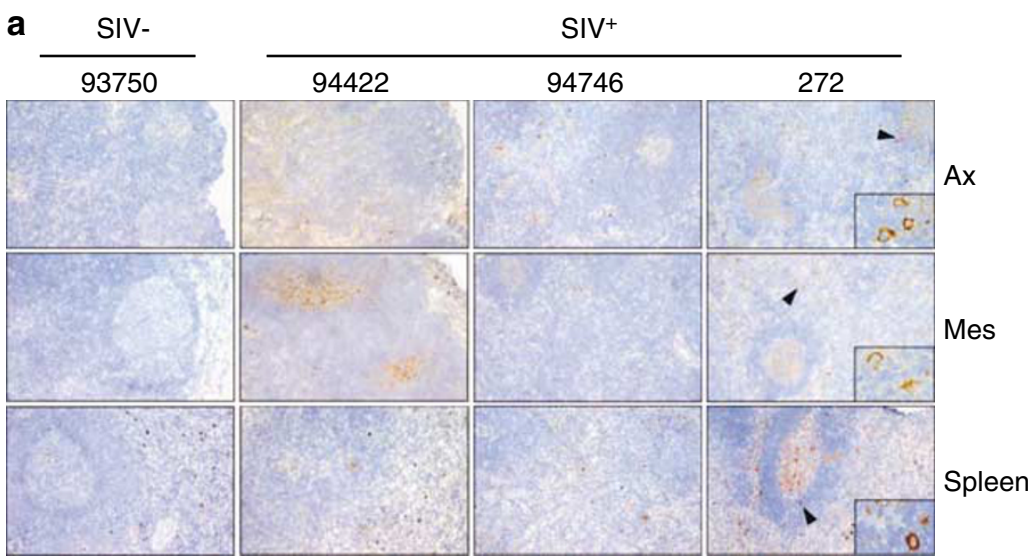

TGF- $\beta 1$

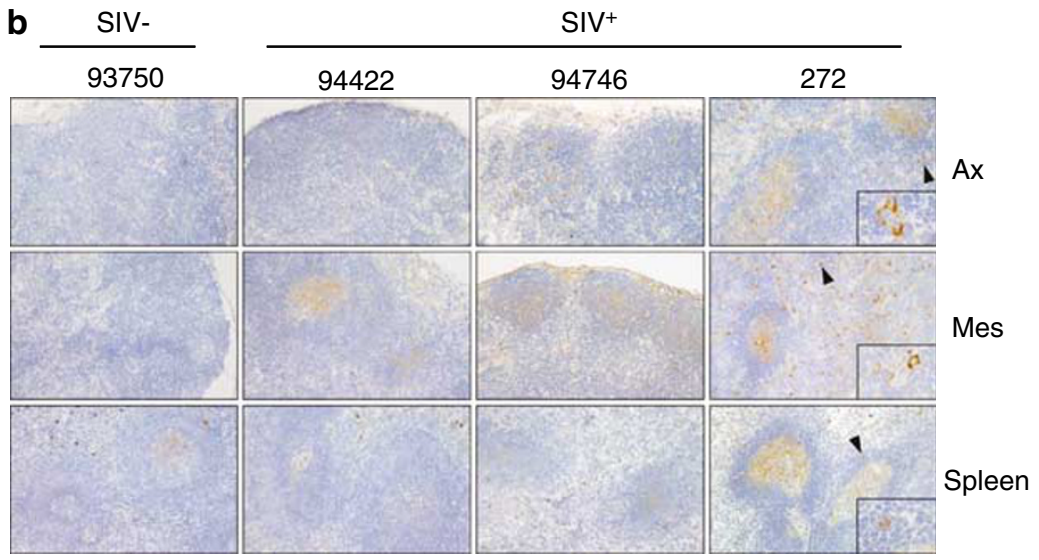

IDO

C

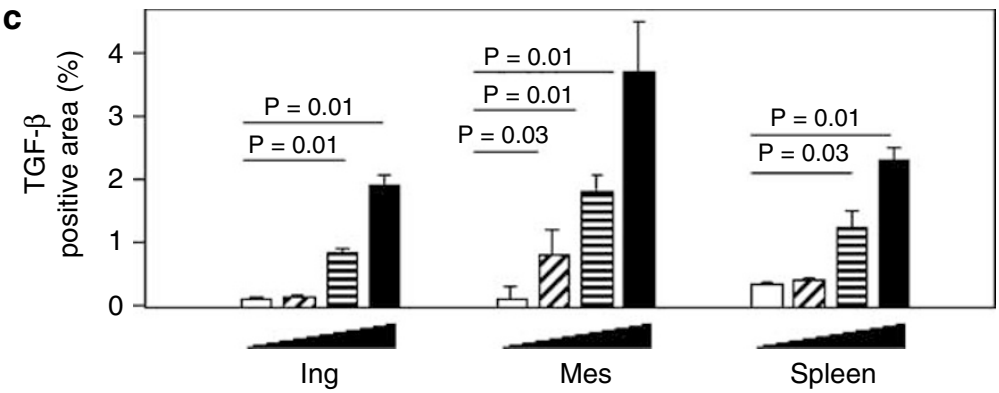

d

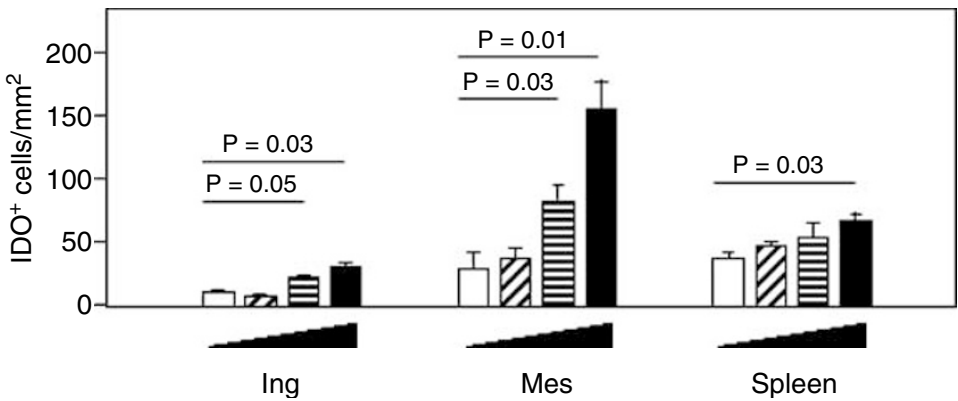

Figure 2 Immunohistochemical analyses of TGF- $\beta$ and IDO expression. (a) TGF- $\beta$ and (b) IDO stainings (magnification, $\times 100$ ). Enlarged detail magnification is shown for positive areas in tissues from \#272 $(\times 400)$. Quantitative assessment of (c) TGF- $\beta$ and (d) IDO expression in tissues from healthy $(\square, n=4)$ and SIV-infected macaques (Z: \#94422, \#264, \#268 (C); E: \#266, \#94438, \#94748, \#94746 (NC); $\mathbf{\square}:$ \#94852, \#272 (NC/FP)). Statistical significance was assessed using the Student's t-test 

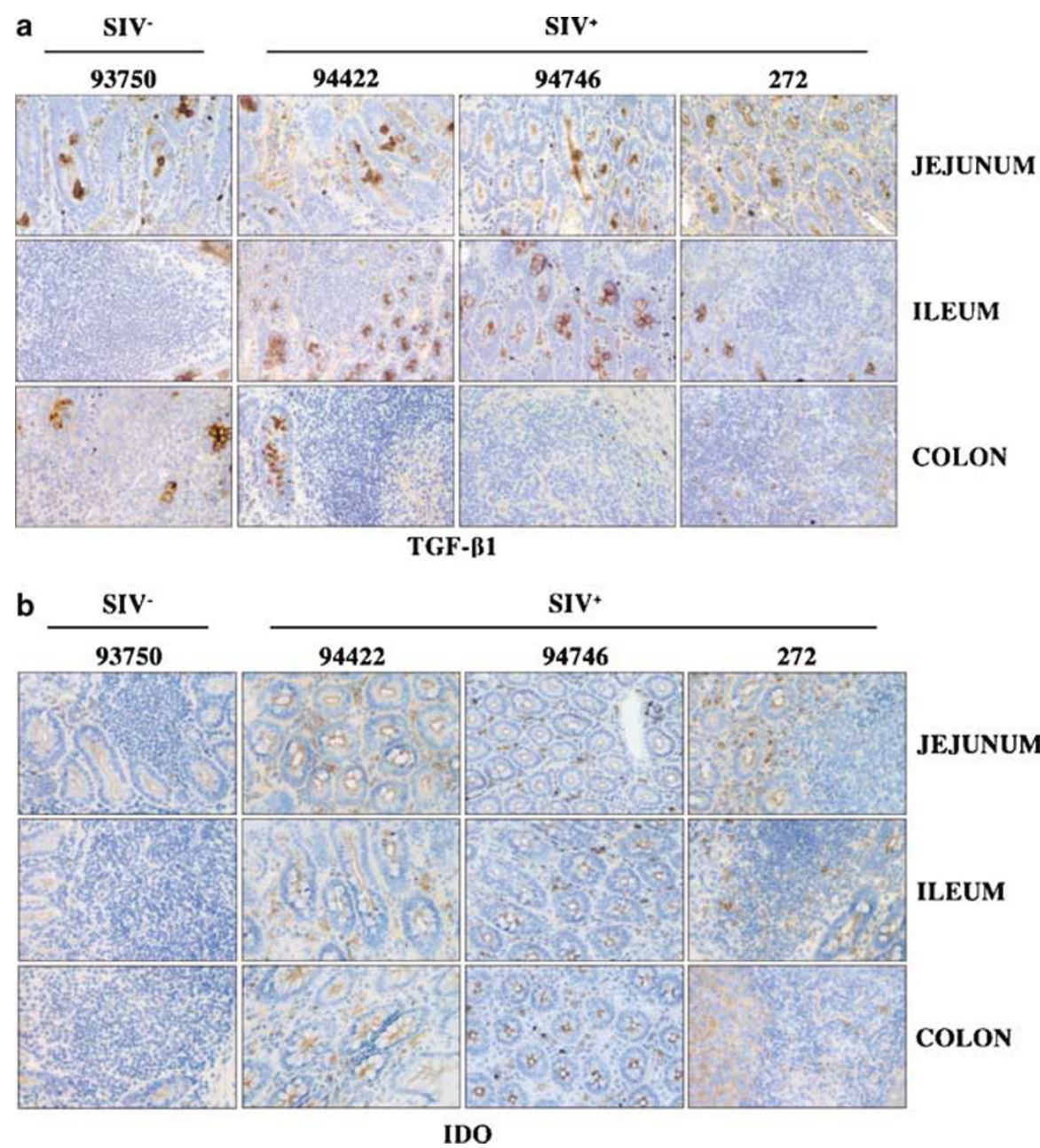

Figure 3 Immunohistochemical analyses of TGF- $\beta$ and IDO expression in jejunum, ileum and colon. (a) TGF- $\beta$ and (b) IDO stainings (magnification, $\times 200$ ) of uninfected (\#93750) and SIV-infected macaques displaying distinct rates of progression toward AIDS (controller \#94422, non-controller \#94746 and non-controller/fast progressor \#272)

SIV-infected macaques than in healthy macaques. Staining with mAbs to CD8 revealed that TIA-1 expression colocalized within the CD8 T-cell zone. More importantly, our data revealed that TIA-1 expression was lower in animals progressing faster to AIDS, compared with controllers (Figures $7 a$ and $b$ ). Although given the current lack of MHC tetramers for Chinese macaques, such an analysis was not feasible, our findings are nevertheless consistent with the notion that the loss of armed $\mathrm{CD} 8{ }^{+} \mathrm{T}$ cells may have a major impact on disease outcome.

Our data also indicated few TIA-1 expressing cells in the jejunum, ileum and colon of the non-controller SIV-infected macaques (Supplementary data, S2), consistent with the low level of viral replication in these tissues (Figure 1). Moreover, no TIA-1 staining was observed in macaque \#272, despite the presence of SIV RNA ${ }^{+}$-positive cells in the GALT. The integrin $\alpha \mathrm{E} \beta 7$ (CD103) is an important molecule for $\mathrm{CD}^{+}{ }^{+} \mathrm{T}$ cells, in particular tethering $T$ cells to adjacent intestinal epithelial cells. We found that CD103 expression was downregulated in SIV-infected tissues (Supplementary data S3). These observations suggest that recirculation of $\mathrm{CD}^{+} \mathrm{T}$ cells might be impaired during SIV infection, resulting in the apparent absence of armed effector T cells in the GALT. This again may be linked to abnormal priming of $\mathrm{CD}^{+} \mathrm{T}$ cells to undergo death in Mes LNs, as shown above.

Impact of TGF- $\beta$ and IDO on CD8 ${ }^{+}$T-cell activation and $^{-}$ death of SIV-infected macaques. Given the higher level of immunosuppressive factors in macaques progressing faster to AIDS, we evaluated their function in a mixed-lymphocyte response (MLR). Cells from Mes LNs of healthy and SIVinfected macaques (\#94852) were irradiated and further incubated with PBMC of controls (donor 1 and 2). Our data demonstrated that Mes LN cells from SIV-infected macaque have a poor capacity to induce MLR compared with Mes LN cells derived from healthy macaque (Figure 8a). Most importantly, we found that neutralizing mAbs against TGF- $\beta$ increased this T-cell proliferation (Figure $8 b$ ). 1-methyl-Dtryptophan (1-MT), that inhibits IDO, increased T-cell proliferation only in donor 2 (Figure $8 \mathrm{~b}$ ), and to a lesser extent. Given the greater propensity of $\mathrm{CD}^{+} \mathrm{T}$ cells from non-controllers to die and that neutralization of TGF- $\beta$ increased T-cell proliferation, we next determined whether inhibition of TGF- $\beta$ would prevent $\mathrm{CD} 8^{+}{ }^{+}$-cell death from 
a
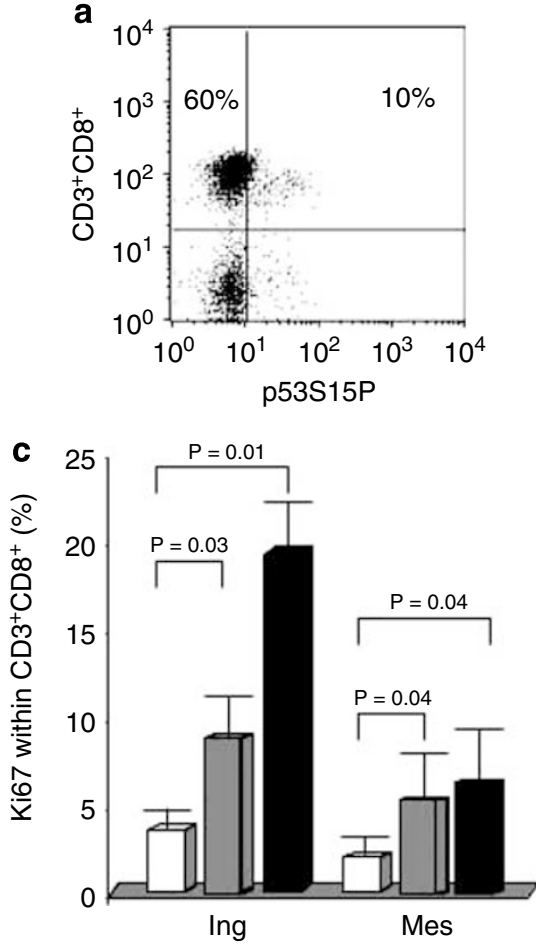

b

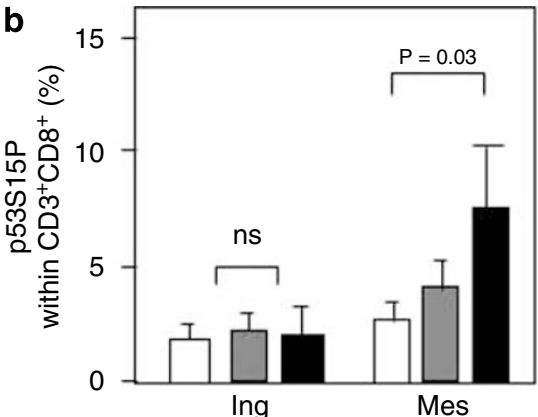

d

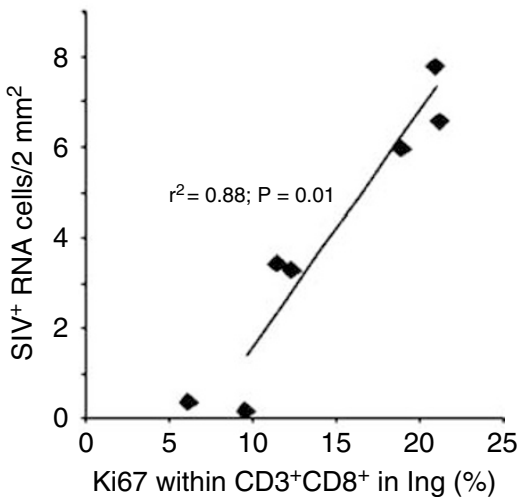

Figure 4 (a) Representative flow cytometric analysis of p53S15P in CD3 ${ }^{+} \mathrm{CD} 8^{+} \mathrm{T}$ cells of an SIV-infected macaque (\#272). Cells were gated on CD3-positive cells. (b) Expression in Ing and Mes LNs of healthy ( $\square, n=3$ ), SIV-infected controller macaques ( $\square$ : \#264, \#268, \#94422 and \#P4) and SIV-infected non-controller macaques ( $\mathbf{\square}$ : \#94748, \#94746, \#94852 and \#272). Statistical significance was assessed using Student's t-test. (c) Percentage of cells expressing Ki67 among CD3 ${ }^{+}$CD8 ${ }^{+}$T cells in $^{2}$ uninfected ( $\square$ ), SIV-infected controller macaques ( $\square$ : \#264, \#268, \#94422 and \#P4) and SIV-infected non-controller macaques ( $\mathbf{\square}$ : \#94746, \#94852 and \#272) was determined by flow cytometry. Significance was assessed using Student's $t$-test. (d) Correlation between the proportion of cycling $\mathrm{CD} 3{ }^{+} \mathrm{CD}{ }^{+}{ }^{+} \mathrm{T}$ cells in $\mathrm{LNs}$ with the extent of viral replication. Significance was assessed using the Spearman Rank Test

non-controllers. While soluble CD95-Fc fusion protein (rhFas-Fc), which blocks CD95/CD95L interaction, had no effect, we found that neutralizing antibodies to TGF- $\beta$ reduced CD3-mediated $\mathrm{CD}^{+}{ }^{+} \mathrm{T}$-cell death (Figure $8 \mathrm{c}$ ). Unfortunately neutralizing antibodies to block the interaction between PD-1 and its counterpart PD-L1 did not cross-react with macaque molecules, preventing us to address its functional involvement. Given that IL-2 was reported to inhibit TGF- $\beta$ as well as PD- 1 signaling, ${ }^{18}$ we treated the cells with IL-2 and found that CD8 ${ }^{+}$T-cell death was reduced. Altogether, our results support the notion that suppressive environmental factors have a major impact on immune response and might be responsible for the death of effector/ memory $\mathrm{CD}^{+}{ }^{+} \mathrm{T}$ cells during SIV infection.

\section{Discussion}

HIV-specific CD8 ${ }^{+}$T lymphocytes (CTL) are considered as crucial in controlling viral replication. ${ }^{19}$ However, HIV/SIVspecific cell-mediated immunity is generally unable to adequately control virus replication. Several lines of evidence indicate that the effectiveness of virus-specific immune responses is not only based on the quantity but also on the quality of $\mathrm{T}$ cells. ${ }^{17,20,21}$

One major finding of our study provides strong evidence that Mes LNs represent major reservoirs not only for animals progressing more rapidly toward AIDS but also in LTNP, in which plasma viral loads were below the level of detection for extended periods of time. The extent of viral replication in the other organs is markedly lower, whereas viral dissemination to non-lymphoid organs appeared only later in the course of SIV infection in macaques of Chinese origin. These findings support the idea that controlling SIV inside Mes LNs may be crucial. Given that Indian rhesus macaques (the predominant model of AIDS) progress more rapidly to disease than Chinese monkeys, ${ }^{22,23}$ the observations performed on macaques \#272, that closely resemble the infection pace in Indian macaques, provided an interesting example of viral dissemination throughout the body associated with a poor prognostic. Thus, our data showing distinct rates of disease progression in Chinese macaques suggest the importance of host factors in the control of viral dissemination.

In this context, we found that expression of TIA-1, which characterized effector/memory $\mathrm{CD}^{+}{ }^{+} \mathrm{T}$ cells, was low in Mes LNs of macaques of Chinese origin progressing faster to AIDS. This contrast with a recent report indicating that Mes LNs from two chronically SIV-infected macaques of Indian origin with disease progression showed increased expression of genes associated with interferon induction and T-cell cytotoxic response, compared to one long-term progressor. ${ }^{24}$ This apparent discrepancy might be related to transcriptional and/or post-transcriptional control of cytotoxic effector molecules, ${ }^{25}$ as we used immunohistochemical analyses for the 
a
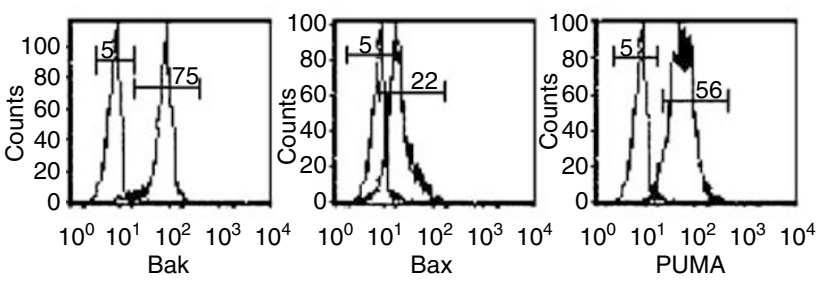

C
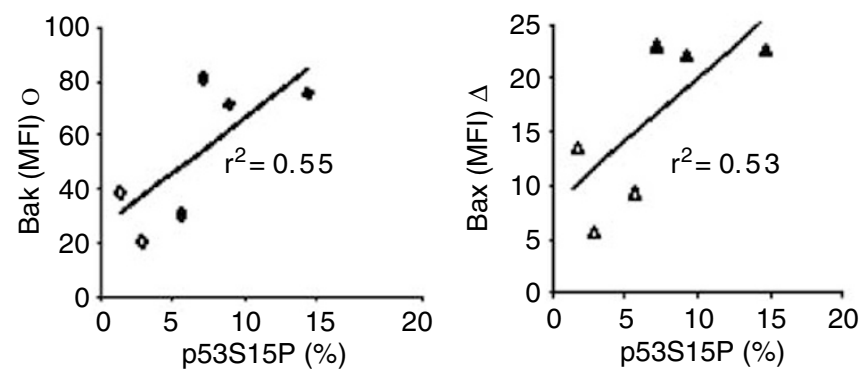
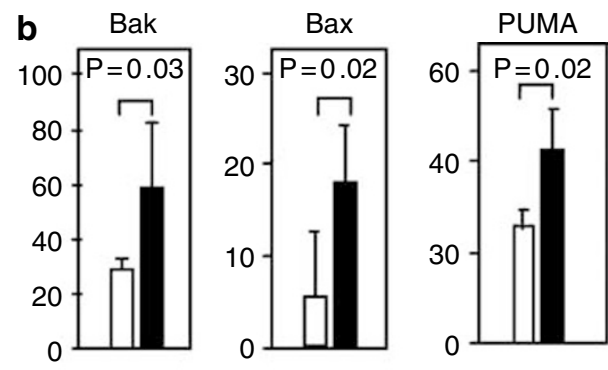

d
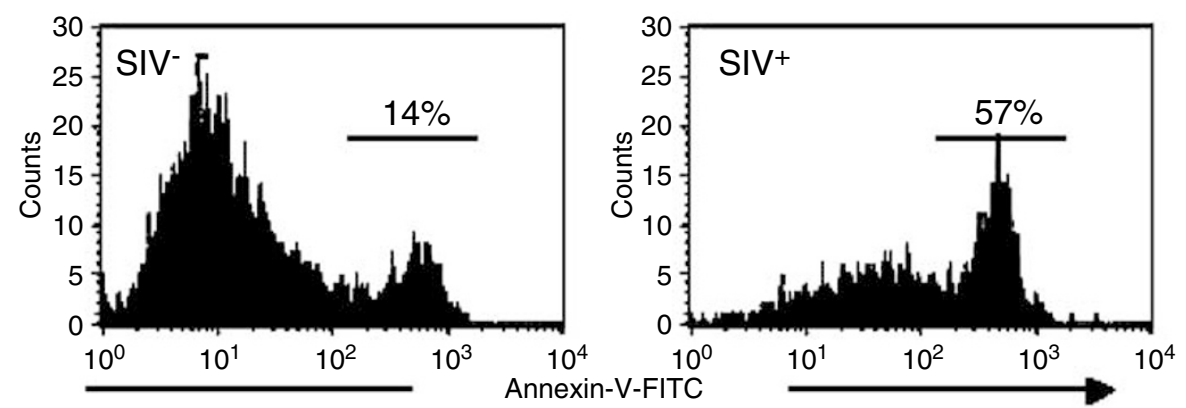

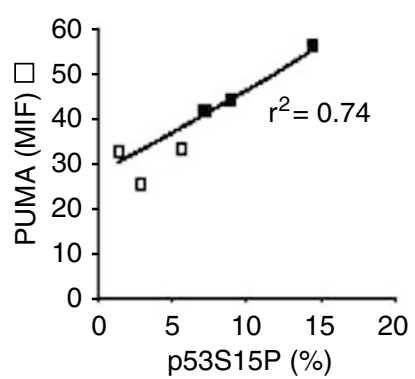

e

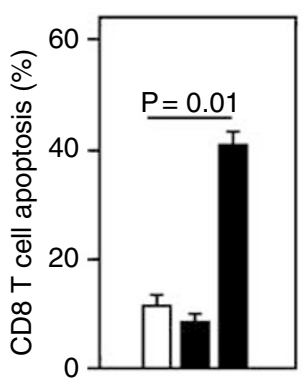

$\mathbf{f}$

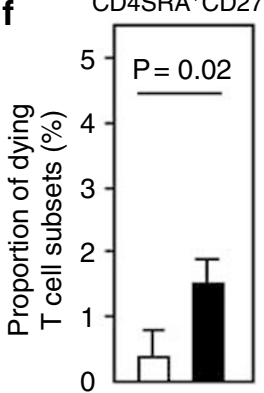

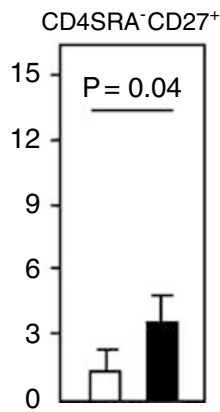
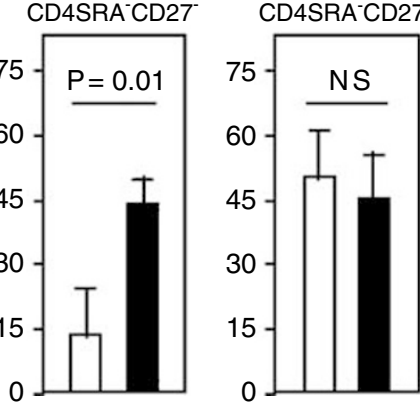

Figure 5 (a) Representative flow cytometric analysis of Bak, Bax and PUMA expression in $\mathrm{CD} 3^{+} \mathrm{CD} 8^{+} \mathrm{T}$ cells of Mes LNs from an SIV-infected macaque (\#272). (b) Expression in Mes LNs of healthy ( $\square, n=4$ ) and SIV-infected macaques ( $\mathbf{\square}$ : \#264, \#268, \#94748, \#94746, \#94852, and \#272). Statistical significance was assessed using Student's t-test. (c) Correlation between p53S15P and Bak, Bax and PUMA expressions. Each symbol represents an individual; controllers (open symbols) and non-controllers (filled symbols). Best-fit lines are shown and regression analyses are indicated in the plots. (d) Representative flow cytometric analysis of phosphatidyl exposure (annexin-V staining) on $\mathrm{CD}^{+}{ }^{+} \mathrm{CD} 8{ }^{+} \mathrm{T}$ cells of Mes LNs from uninfected (SIV ${ }^{-}$) and SIV-infected macaques (SIV ${ }^{+}$, \#272). (e) Percentage of dying CD3 ${ }^{+} \mathrm{CD} 8^{+} \mathrm{T}_{\text {cells in Mes } \mathrm{LNs} \text { of }}$ healthy ( $\square, n=4$ ), SIV-infected controller macaques ( $\square$ : \#P4, \#264, \#268, \#94422) and SIV-infected non-controller macaques ( $\mathbf{\square}$ : \#266, \#94780, \#94438, \#94748, \#94746, \#94852 and \#272). (f) Proportions of CD3 ${ }^{+} \mathrm{CD}^{+}{ }^{+}$T-cell subsets that are prone to die from Mes LNs of healthy $(\square, n=4)$ and SIV-infected macaques ( $\square$ : \#94438, \#94748, and \#94746 and \#94852) (*: $P<0.05)$

detection of protein. Indeed, consistent with our data, a defect in perforin expression was shown in intestinal tissues of HIVinfected individuals based on this technique. ${ }^{25}$ The low levels of TIA-1 cells in lymphoid tissues of controllers compared with non-controllers may also suggest that effector/memory CD8 ${ }^{+}$ $\mathrm{T}$ cells, which represent a highly activated population, have already degranulated. However, we attempted to minimize this issue by performing the analysis of expression of TIA-1 in situ, rather than in isolated lymphocytes, since the isolation procedure itself might have induced degranulation.

Most importantly, we found that the $\mathrm{TIA}-1^{+}$-defined effector/memory $\mathrm{CD}^{+}{ }^{+} \mathrm{T}$ cells, ${ }^{17}$ from Mes LNs, were 

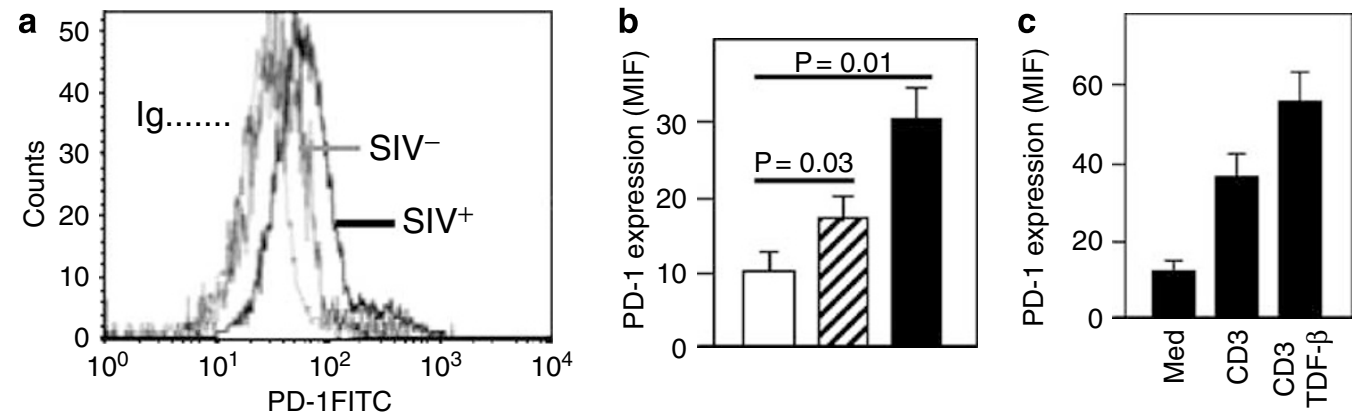

Figure 6 Expression of PD-1. (a) Representative flow cytometric analysis of PD-1 expression on CD3 ${ }^{+} \mathrm{CD}^{+}{ }^{+}$cells of Mes LNs from either uninfected (SIV ${ }^{-}$) or SIVinfected macaques (SIV ${ }^{+}$, \#94852). Cells were first gated on CD3 ${ }^{+}$T cells. (b) Expression in Mes LNs of healthy $(\square, n=4)$ and SIV-infected controller macaques (Z: \#264, \#268, \#94422) and SIV-infected non-controller macaques ( $\mathbf{\square}$ : \#94748, \#94746, \#94852 and \#272). Statistical significance was assessed using Student's t-test. (c) TGF- $\beta$ enhances CD3-mediated PD-1 expression on $\mathrm{CD}^{+}{ }^{+} \mathrm{CD} 8{ }^{+}$T cells. Cells were stimulated with CD3 mAbs in the absence (CD3) or presence of TGF- $\beta$ (CD3TGF- $\beta, 50 \mathrm{ng} / \mathrm{ml}$ )
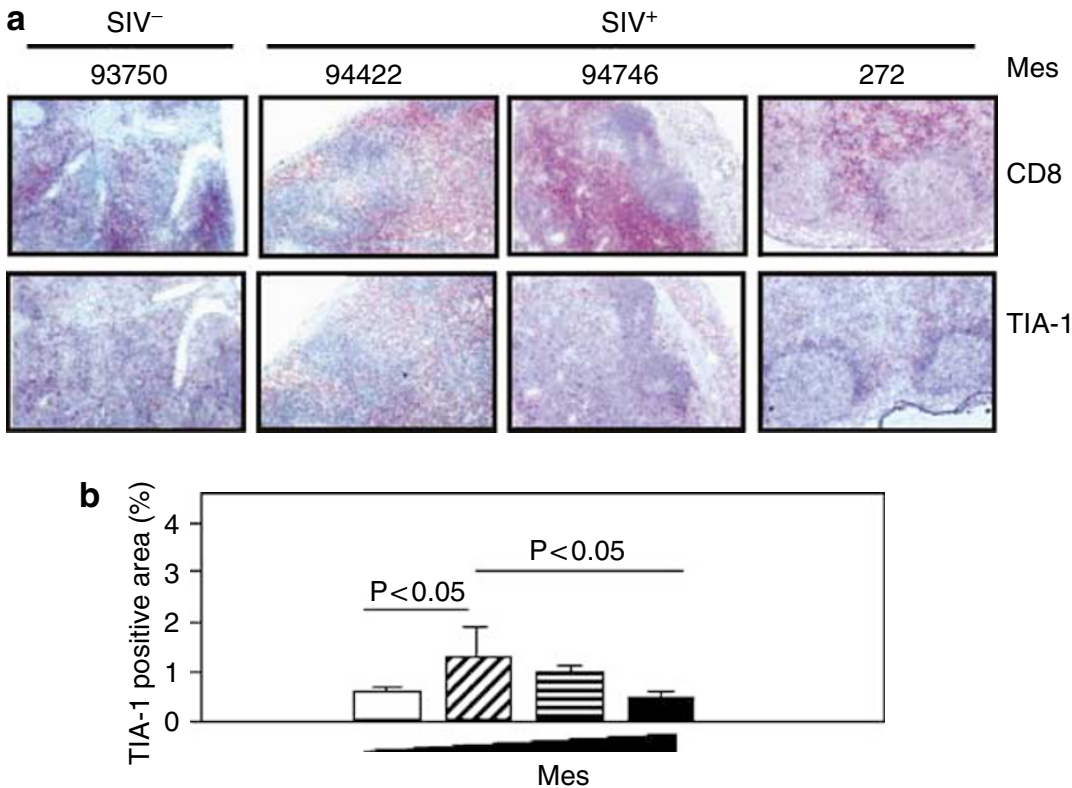

Figure 7 (a) Immunohistochemical analyses of CD8 and TIA-1 expression in Mes LNs (magnification, $\times 100$ ) of uninfected (\#93750) and SIV-infected macaques displaying distinct rate of progression toward AIDS (controller, \#94422 and non-controllers, \#94746 and \#272). (b) Quantitative assessment of TIA-1 expression from healthy $(\square, n=4)$ and SIV-infected controller macaques (Z: \#94422, \#264, \#268) SIV-infected non-controller macaques (E: \#266, \#94438, \#94748, \#94746) and SIV-infected fast progressors ( $\mathbf{\square}$ : \#94852 and \#272). Statistical significance was assessed using Student's $t$-test

abnormally primed for death in SIV-infected monkeys, with higher priming in non-controllers than in controllers. Thus, we demonstrated that in addition to peripheral blood, ${ }^{26-28} \mathrm{CD}^{+}$ T cells from secondary lymphoid organs are more prone to die during chronic SIV infection. Consistent with abnormal programmed cell death, we demonstrated greater expression of Bax and Bak activation concomitant with the phosphorylation of p53 on serine 15 in $\mathrm{CD}^{+}{ }^{+} \mathrm{T}$ cells of non-controllers. Bax and Bak are considered as the main effectors involved in the destabilization of the mitochondria and cell death. Interestingly, it has been recently reported that sensitize $\mathrm{CD}^{+} \mathrm{T}$ cells for death during LCMV infection with bisindoIylmaleimide VIII impairs cytotoxicity and viral clearance. ${ }^{29}$ Thus, the consequence of the absence of armed effector cells in Mes LNs will be an inadequate 'immune barrier' unable to contain the virus inside the reservoirs and contribute to immune incompetence during SIV infection.

It has been reported a decade ago that PBMC of HIVinfected individuals overexpress TGF- $\beta{ }^{30}$ More recently, increased expression of IDO and TGF- $\beta$ was reported in LNs during the acute phase of SIV-infected macaques. ${ }^{7}$ Our study indicates that the immunologic sources of IDO and TGF- $\beta$ are mostly non-lymphoid cells. Similar cell lineages have been identified in various models: recombinant virusimmunized mice, and tumor bearing mice. ${ }^{31,32}$ However, the mechanisms by which these immunosupressive factors are induced remain unclear. TGF- $\beta$ entertains a complicated relationship with T-cell activation and death. Thus, TGF- $\beta$ significantly enhances growth/survival of naive $\mathrm{CD} 8^{+} \mathrm{T}$ cells, but inhibits proliferation of activated T cells. ${ }^{33}$ We have shown 

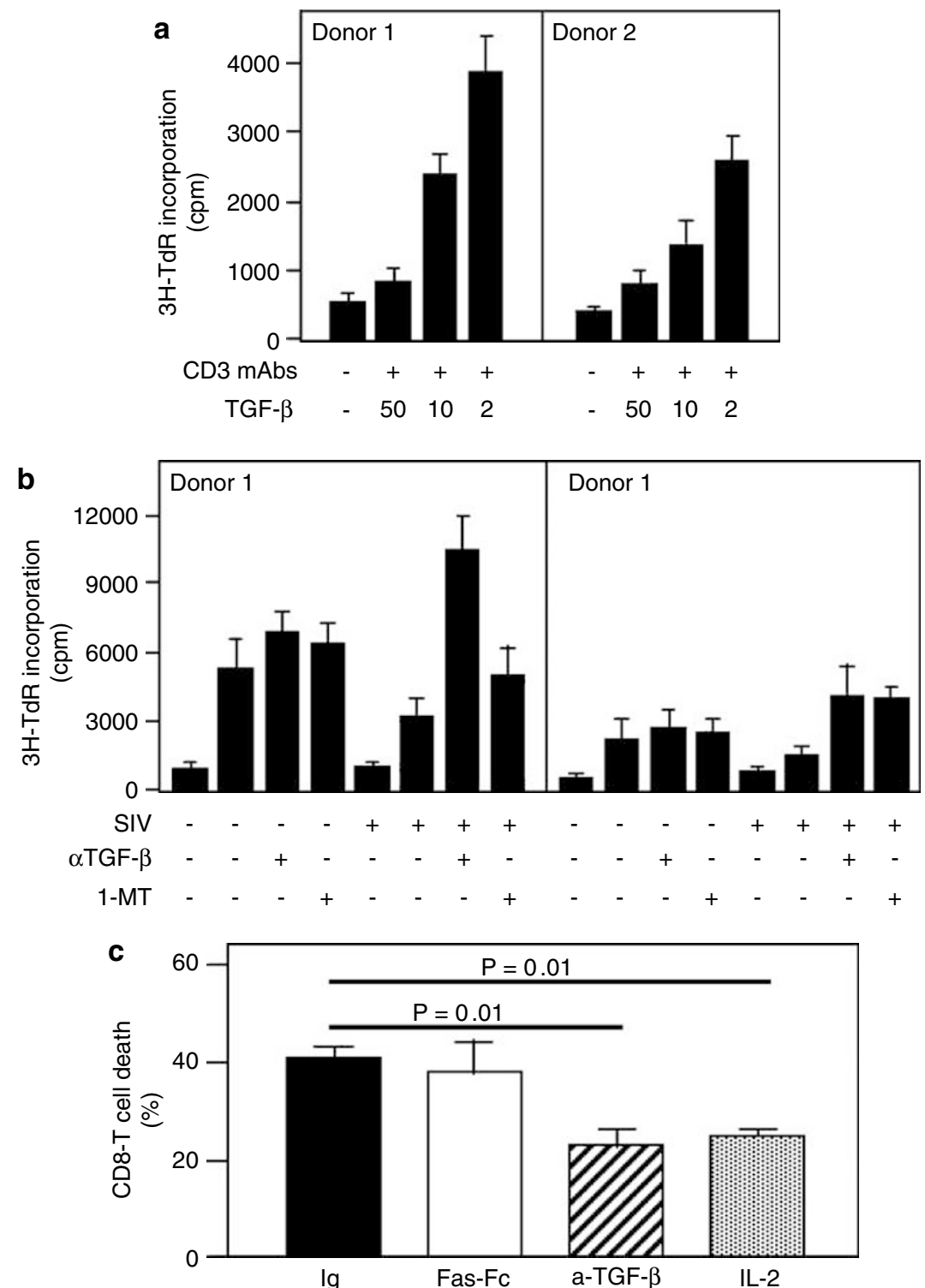

Figure 8 (a) TGF- $\beta$ inhibited CD3-mediated T-cell proliferation. Cells of controls (donors 1 and 2$)$ were stimulated with CD3 mAbs in the absence $(-)$ or presence $(+)$ of TGF- $\beta(50,10$ and $2 \mathrm{ng} / \mathrm{ml})$. (b) Neutralization of TGF- $\beta$ restored T-cell proliferation. PBMC from controls (donors 1 and 2 ) were incubated with irradiated Mes LN cells from either uninfected (SIV -) or SIV-infected macaques (SIV + , \#94852). Cells were incubated in the absence $(-)$ or presence $(+)$ of either neutralizing TGF- $\beta \mathrm{mAbs}(10 \mu \mathrm{g} / \mathrm{ml})$ or 1-MT $(500 \mu \mathrm{M})$. (c) Neutralization of TGF- $\beta$ reduced CD8 ${ }^{+}$T-cell death induced by CD3 (AICD). Mes LNs (\#94748, \#94746 and \#94852) were incubated with anti-CD3 in the absence of presence of anti-TGF- $\beta$, Fas-Fc and IL-2 $(20 \mathrm{ng} / \mathrm{ml})$. Death was assessed after overnight culture and quantified by flow cytometry using labeled annexin-V

here that blocking TGF- $\beta$ by neutralizing antibody increased MLR and reduced activation-induced cell death (AICD)mediated $\mathrm{CD}^{+}{ }^{+}$T-cell death, whereas blocking IDO was less potent in restoring T-cell proliferation. Several groups have recently reported that PD-1 expression on peripheral blood $\mathrm{CD}^{+}{ }^{+} \mathrm{T}$ cells is increased during HIV infection and regulate T-cell survival. ${ }^{34-36}$

Herein, we also demonstrated that induction of PD-1 is increased in Mes LNs of non-controllers and expression of PD-1 is enhanced in vitro by TGF- $\beta$. Although, we speculate a role of PD-1 in Mes LNs favoring immunosupression, a formal proof that blockade of PD-1/PD-L1 interaction will restore T-cell function and prevent death remains to be addressed once adequate reagents are available. In HIV-infected individuals, it has been shown that blocking such interaction increases the capacity of peripheral blood HIV-specific CD8 ${ }^{+}$ T cells to proliferate and survive. ${ }^{34-36}$ While TGF- $\beta$ appears necessary to prime cells of SIV-infected macaques to undergo apoptosis, it is not sufficient in and by itself to fully induce the process, as we have been unable to induce death by simply adding TGF- $\beta$ on T cells from healthy macaques, in spite of inducing PD-1 expression. This may however reflect the lack of PD-L1 expression in our in vitro culture system. Taken together, our results support the notion that a second signal is required to program T cells to die even though TGF- $\beta$ is by itself able to inhibit their proliferation. Interestingly, our results underline the role of the transcription factor p53 that are expressed at higher levels in $\mathrm{CD}^{+}{ }^{+} \mathrm{T}$ cells from macaques 
progressing faster to Aids. Thus, TGF- $\beta$ could be the arming signal 1 and the death molecules (signal 2), the executioners of the effector/memory CD8 ${ }^{+}$T cells in Mes LNs. Moreover, given that IDO is responsible for downmodulating $\mathrm{T}$-cell proliferation, ${ }^{11}$ while PD-1 limits glucose metabolism, ${ }^{37}$ their concerted expression may be a multi-pronged strategy to enforce $\mathrm{T}$ lymphocyte inhibition by disrupting cellular metabolism which is required for cell survival. Thus, triggering multiple negative regulators of $\mathrm{T}$-cell activation will likely be far more effective at dysregulating T-cell activation during SIV infection than the actions of any single inhibitor.

These findings are particularly novel in the sense that a current view is that generalized immune activation is a determinant of disease progression in HIV/SIV infections. ${ }^{38}$ While we clearly found a positive correlation between the extent of viral replication in peripheral lymphoid tissues (e.g. Figure $4 d$ ) and the rate of cycling cells in LNs, consistent with previous findings, ${ }^{13,14}$ our data revealed a markedly distinct picture in Mes LNs. Thus, the positive relationship in peripheral LNs might be a consequence of the relapse of SIV from reservoir sites and reflects active antiviral defenses and likely protective responses. Blockade of T-cell costimulation based on in vivo administration of CTLA4-Ig and antiCD40L mAbs during primary SIV infection has been reported to induce a more rapid clinical deterioration in inducing AIDS as compared with control SIV-infected macaques. ${ }^{39}$ Therefore, induction of immune tolerance appears detrimental rather than beneficial during HIV/SIV infections of humans and macaques respectively.

Thus, we have defined new critical pathways and potential markers involved in the dysregulation of immune response during chronic SIV infection that may provide insights for new approaches for AIDS immunotherapy.

\section{Materials and Methods}

Animals, virus infection and tissue collection. Rhesus macaques (Macaca mulatta) of Chinese origin that had been housed and cared for in accordance with European guidelines were inoculated intravenously with $1050 \%$ animal-infectious doses $\left(\mathrm{AID}_{50}\right)$ of the pathogenic SIVmac251 strain. The organs were collected and frozen in isopentane cooled in liquid nitrogen. Organs were cut into $4 \mu \mathrm{m}$ sections on a cryostat and the sections were stored at $-80^{\circ} \mathrm{C}$ until use. ${ }^{40}$

Viral quantification. Quantification of plasma SIV RNA levels was assessed by real-time quantitative reverse transcriptase-polymerase chain reaction (RT$\mathrm{PCR}),{ }^{40}$ and viral replication in tissues was assessed by in situ hybridization using a ${ }^{35} \mathrm{~S}$-labeled RNA probe derived from pBluescript encoding the SIVmac nef gene, as previously described. ${ }^{40}$

Immunohistochemical analyses. Slides were immunostained using antibodies directed against integrin $\alpha \mathrm{E} \beta 7$ (CD103) (2G5, Coulter Coultronics Inc.), TGF- $\beta 1$ (9016, RD Systems), IDO (Chemicon) and IL-10 (JES3-9D7, Biosource). For TGF- $\beta 1, \mathrm{IL}-10$ and IDO, the sections were fixed in $2 \%$ paraformaldehyde and permeabilized with Triton $0.05 \%$. We assessed TIA-1 expression (clone GMP-17, Beckman Coulter), a polyadenylate binding protein localized to the granules of cytolytic $T$ cells, and functionally related to perforin. We assessed TIA-1 expression in situ to exclude the possibility that isolated lymphocytes might release their granule contents during the isolation procedure. These analyses were performed on four different slides, in a blind manner, by two investigators. The numbers of cells counted were then divided by the surface of the entire lymph node section. The results were expressed as cell numbers $/ 2 \mathrm{~mm}^{2}$ sections. Semi-quantitative analyses were also determined by measuring the level of staining (numbers of pixels of the entire lymph node section) divided by the total surface. The results were expressed as a percentage of staining.
Lymphocyte immunophenotyping and flow cytometry. $\mathrm{CD} 4^{+}$and $\mathrm{CD}^{+}{ }^{+}$cells were quantified by flow cytometry using the following antibodies: antiCD3-PE, anti-human CD4-APC and anti-human CD8-PerCP. Antibodies to PD-1 were purchased from eBiosciences. Antibodies were added to the cells and incubated, as previously described. ${ }^{17}$ For intracellular staining, the cells were fixed and permeabilized before incubation with anti-Ki67-FITC (clone MIB-1, Coultronics), or unlabeled anti-phospho-p53 (Ser15, Cell Signalling), Bax (BD biosciences), Bak (Calbiochem) and PUMA (Stressgen). After washing, FITC-labeled goat anti-rabbit IgG antibody was added to anti-phospho-p53. Cells were analyzed by flow cytometry. A total of 10000 events in the lymphocyte gate were analyzed using CellQuest software (BD Biosciences). All analyses were performed with a FACScalibur flow cytometer (BD Biosciences).

T-cell proliferation. PBMC from healthy macaques were cultured in RPMI medium supplemented with $10 \%$ fetal calf serum at $2 \times 10^{5} / \mathrm{ml}$ in 96 -well culture plates, in the presence or absence of CD3 mAbs $(1 \mu \mathrm{g} / \mathrm{ml}$, Biosource), and in the absence or presence of recombinant TGF- $\beta$ (R\&D Systems) for 4 days. ${ }^{3} \mathrm{H}$ thymidine ( $0.5 \mu \mathrm{Ci}$ per well, Amersham) was added during the last $10 \mathrm{~h}$ culture, and cells were harvested and counted on a Microbeta-plate -counter (Beckman Coulter). Triplicate wells containing irradiated Mes LN cells derived from healthy and SIVinfected macaques $\left(2 \times 10^{5}\right.$ cells) were cultured with PBMC from healthy donors $\left(2 \times 10^{5}\right.$ cells) for 4 days. Cells were cultured in the presence or absence of either neutralizing antibodies against TGF- $\beta 1$ and $-\beta 2$ (R\&D Systems and Sigma, respectively) at $10 \mu \mathrm{g} / \mathrm{ml}$ or $1-\mathrm{MT}$ ( $500 \mu \mathrm{M}$, Sigma).

Cell death quantification. Cells were incubated for $24 \mathrm{~h}$ at $37^{\circ} \mathrm{C}$ with $5 \%$ of $\mathrm{CO}_{2}$ in RPMl 1640 supplemented with $10 \%$ fetal calf serum (AbCys), penicillin $(50 \mathrm{U} / \mathrm{ml})$, streptomycin $(50 \mathrm{U} / \mathrm{ml})$, glutamine $(2 \mathrm{mM})$ and sodium pyruvate $(1 \mathrm{~mm})$. Cells were activated with CD3 mAbs $(1 \mu \mathrm{g} / \mathrm{ml}$; Biosource) in the absence or presence of recombinant Fas-Fc ( $10 \mu \mathrm{g} / \mathrm{ml}$, Alexis Corporation), neutralizing TGF- $\beta$ $\mathrm{mAbs}(10 \mu \mathrm{g} / \mathrm{ml})$ and IL-2 (10 ng/ml, R\&D Systems). Cell death was assessed by flow cytometry, as previously described. ${ }^{26}$ Briefly, after staining with specific antibodies ( $30 \mathrm{~min}$ at $4{ }^{\circ} \mathrm{C}$ ), cells were washed and then incubated with fluorescently labeled annexin- $\mathrm{V}\left(20 \mathrm{~min}\right.$ at $\left.4^{\circ} \mathrm{C}\right)$, and 10000 events were analyzed with a FACScalibur flow cytometer.

Statistical analyses. Data were compared using Student's t-test or MannWhitney U-test (Prism software), and the confidence interval of the regression analysis was determined using the Spearman Rank test (Statistica software). Differences were considered to be significant if $P<0.05$.

Acknowledgements. The authors are grateful to Dr. J Berzofsky (National Cancer Institute, Bethesda, USA) and Dr. Y Lévy (Hôpital Henri-Mondor, Créteil, France) for critically reading the manuscript and for helpful comments. We also acknowledge JM Panaud (Institut Pasteur) for pictures and AM Aubertin (INSERM U-74, Strasbourg) for kindly providing virus. We apologize to the authors of relevant articles that are not cited because of space limitations. This work was funded by grants from the Agence Nationale de la Recherche sur le Sida (ANRS) and Fondation de la Recherche Médicale (FRM) to JE. VL was supported by a fellowship from ANRS and LS by a postdoctoral fellowship from SIDACTION.

1. Blankson JN, Persaud D, Siliciano RF. The challenge of viral reservoirs in HIV-1 infection. Annu Rev Med 2002; 53: 557-593.

2. Schmitz JE, Kuroda MJ, Santra S, Sasseville VG, Simon MA, Lifton MA et al. Control of viremia in simian immunodeficiency virus infection by CD8+ lymphocytes. Science 1999; 283: 857-860

3. Hurtrel B, Petit F, Arnoult D, Muller-Trutwin M, Silvestri G, Estaquier J. Apoptosis in SIV infection. Cell Death Differ 2005; 12 (Suppl 1): 979-990.

4. Pantaleo G, Graziosi C, Demarest JF, Butini L, Montroni M, Fox CH et al. HIV infection is active and progressive in lymphoid tissue during the clinically latent stage of disease. Nature 1993: 362: 355-358.

5. Veazey RS, DeMaria M, Chalifoux LV, Shvetz DE, Pauley DR, Knight HL et al. Gastrointestinal tract as a major site of $\mathrm{CD} 4+\mathrm{T}$ cell depletion and viral replication in SIV infection. Science 1998; 280: 427-431.

6. Heise C, Vogel P, Miller CJ, Halsted CH, Dandekar S. Simian immunodeficiency virus infection of the gastrointestinal tract of rhesus macaques. Functional, pathological, and morphological changes. Am J Pathol 1993; 142: 1759-1771. 
25. Shacklett BL, Cox CA, Quigley MF, Kreis C, Stollman NH, Jacobson MA et al. Abundant expression of granzyme A, but not perforin, in granules of CD8+ T cells in GALT: implications for immune control of HIV-1 infection. J Immunol 2004; 173 641-648.

of an immunosuppressive regulatory $T$ cell response during acute simian immunodeficiency virus infection. J Infect Dis 2006; 193: 703-712.

8. Schacker TW, Nguyen PL, Beilman GJ, Wolinsky S, Larson M, Reilly C et al. Collagen deposition in HIV-1 infected lymphatic tissues and T cell homeostasis. J Clin Invest 2002; 110: $1133-1139$.

9. Kingsley DM. The TGF-beta superfamily: new members, new receptors, and new genetic tests of function in different organisms. Genes Dev 1994; 8: 133-146.

10. O'Garra A, Vieira P. Regulatory T cells and mechanisms of immune system control. Nat Med 2004; 10: 801-805.

11. Mellor AL, Munn DH. IDO expression by dendritic cells: tolerance and tryptophan catabolism. Nat Rev Immunol 2004; 4: 762-774.

12. Cordenonsi M, Dupont S, Maretto S, Insinga A, Imbriano C, Piccolo S. Links between tumor suppressors: $p 53$ is required for TGF-beta gene responses by cooperating with Smads. Cell 2003; 113: 301-314.

13. Monceaux V, Ho Tsong Fang R, Cumont MC, Hurtrel B, Estaquier J. Distinct cycling CD4(+)- and CD8(+)-T-cell profiles during the asymptomatic phase of simian immunodeficiency virus SIVmac251 infection in rhesus macaques. $J$ Virol 2003; 77: 10047-10059.

14. Sachsenberg N, Perelson AS, Yerly S, Schockmel GA, Leduc D, Hirschel B et al. Turnover of CD4+ and CD8+ T lymphocytes in HIV-1 infection as measured by Ki-67 antigen. J Exp Med 1998; 187: 1295-1303

15. Ishida $Y$, Agata $Y$, Shibahara K, Honjo T. Induced expression of PD-1, a novel member of the immunoglobulin gene superfamily, upon programmed cell death. EMBO J 1992; 11 3887-3895.

16. Barber DL, Wherry EJ, Masopust D, Zhu B, Allison JP, Sharpe AH et al. Restoring function in exhausted CD8 T cells during chronic viral infection. Nature 2006; 439: 682-687.

17. Monceaux V, Viollet L, Petit F, Ho Tsong Fang R, Cumont MC, Zaunders J et al. CD8+ $T$ cell dynamics during primary simian immunodeficiency virus infection in macaques: relationship of effector cell differentiation with the extent of viral replication. $J$ Immuno 2005; 174: 6898-6908.

18. Gunnlaugsdottir B, Maggadottir SM, Ludviksson BR. Anti-CD28-induced co-stimulation and TCR avidity regulates the differential effect of TGF-beta1 on CD4+ and CD8+ naive human T-cells. Int Immunol 2005; 17: 35-44.

19. Jin X, Bauer DE, Tuttleton SE, Lewin S, Gettie A, Blanchard J et al. Dramatic rise in plasma viremia after $\mathrm{CD} 8(+) \mathrm{T}$ cell depletion in simian immunodeficiency virus-infected macaques. J Exp Med 1999; 189: 991-998.

20. Migueles SA, Laborico AC, Shupert WL, Sabbaghian MS, Rabin R, Hallahan CW et al. HIV-specific CD8+ T cell proliferation is coupled to perforin expression and is maintained in nonprogressors. Nat Immunol 2002; 3: 1061-1068.

21. Betts MR, Nason MC, West SM, De Rosa SC, Migueles SA, Abraham J et al. HIV nonprogressors preferentially maintain highly functional HIV-specific CD8+ T cells. Blood 2006; 107: 4781-4789.

22. Reimann KA, Parker RA, Seaman MS, Beaudry K, Beddall M, Peterson L et al. Pathogenicity of simian-human immunodeficiency virus SHIV-89.6P and SIVmac is attenuated in cynomolgus macaques and associated with early T-lymphocyte responses. $J$ Virol 2005; 79: 8878-8885

23. Ling B, Veazey RS, Luckay A, Penedo C, Xu K, Lifson JD et al. SIV(mac) pathogenesis in rhesus macaques of Chinese and Indian origin compared with primary HIV infections in humans. AIDS 2002; 16: 1489-1496.

24. George MD, Verhoeven D, McBride Z, Dandekar S. Gene expression profiling of gut mucosa and mesenteric lymph nodes in simian immunodeficiency virus-infected macaques with divergent disease course. J Med Primatol 2006; 35: 261-269.
26. Arnoult D, Petit F, Lelievre JD, Lecossier D, Hance A, Monceaux V et al. Caspase dependent and -independent T-cell death pathways in pathogenic simian immunodeficiency virus infection: relationship to disease progression. Cell Death Differ 2003; 10: 1240-1252.

27. Estaquier J, Idziorek T, Zou W, Emilie D, Farber CM, Bourez JM et al. T helper type 1/T helper type 2 cytokines and T cell death: preventive effect of interleukin 12 on activationinduced and CD95 (FAS/APO-1)-mediated apoptosis of CD4+ T cells from human immunodeficiency virus-infected persons. J Exp Med 1995; 182: 1759-1767.

28. Estaquier J, Tanaka M, Suda T, Nagata S, Golstein P, Ameisen JC. Fas-mediated apoptosis of $\mathrm{CD} 4+$ and $\mathrm{CD} 8+\mathrm{T}$ cells from human immunodeficiency virus-infected persons: differential in vitro preventive effect of cytokines and protease antagonists. Blood 1996; 87: 4959-4966.

29. Wasem C, Arnold D, Saurer L, Corazza N, Jakob S, Herren S et al. Sensitizing antigenspecific CD8+ T cells for accelerated suicide causes immune incompetence. J Clin Invest 2003; 111: 1191-1199.

30. Kekow J, Wachsman W, McCutchan JA, Cronin M, Carson DA, Lotz M. Transforming growth factor beta and noncytopathic mechanisms of immunodeficiency in human immunodeficiency virus infection. Proc Natl Acad Sci USA 1990; 87: 8321-8325.

31. Terabe M, Matsui S, Park JM, Mamura M, Noben-Trauth N, Donaldson DD et al Transforming growth factor-beta production and myeloid cells are an effector mechanism through which CD1d-restricted $\mathrm{T}$ cells block cytotoxic $\mathrm{T}$ lymphocyte-mediated tumor immunosurveillance: abrogation prevents tumor recurrence. J Exp Med 2003 198: 1741-1752.

32. Bronte V, Wang M, Overwijk WW, Surman DR, Pericle F, Rosenberg SA et al. Apoptotic death of $C D 8+T$ lymphocytes after immunization: induction of a suppressive population of Mac-1+/Gr-1+ cells. J Immunol 1998; 161: 5313-5320.

33. Cerwenka A, Swain SL. TGF-beta1: immunosuppressant and viability factor for T lymphocytes. Microbes Infect 1999; 1: 1291-1296.

34. Day CL, Kaufmann DE, Kiepiela P, Brown JA, Moodley ES, Reddy S et al. PD-1 expression on HIV-specific T cells is associated with T-cell exhaustion and disease progression. Nature 2006; 443: 282-283

35. Trautmann L, Janbazian L, Chomont N, Said EA, Wang G, Gimmig S et al. Upregulation of PD-1 expression on HIV-specific CD8+ T cells leads to reversible immune dysfunction. $\mathrm{Nat}$ Med 2006; 12: 1198-1202.

36. Petrovas C, Casazza JP, Brenchley JM, Price DA, Gostick E, Adams WC et al. PD-1 is regulator of virus-specific CD8+ T cell survival in HIV infection. J Exp Med 2006; 203 2281-2292.

37. Parry RV, Chemnitz JM, Frauwirth KA, Lanfranco AR, Braunstein I, Kobayashi SV et al. CTLA-4 and PD-1 receptors inhibit T-cell activation by distinct mechanisms. Mol Cell Biol 2005; 25: 9543-9553.

38. Silvestri G, Sodora DL, Koup RA, Paiardini M, O'Neil SP, McClure HM et al. Nonpathogenic SIV infection of sooty mangabeys is characterized by limited bystander immunopathology despite chronic high-level viremia. Immunity 2003; 18: 441-452.

39. Garber DA, Silvestri G, Barry AP, Fedanov A, Kozyr N, McClure H et al. Blockade of T cell costimulation reveals interrelated actions of $\mathrm{CD} 4+$ and $\mathrm{CD} 8+\mathrm{T}$ cells in control of SIV replication. J Clin Invest 2004; 113: 836-845.

40. Monceaux V, Estaquier J, Fevrier M, Cumont MC, Riviere Y, Aubertin AM et al. Extensive apoptosis in lymphoid organs during primary SIV infection predicts rapid progression towards AIDS. AIDS 2003; 17: 1585-1596. 